\title{
MAXIMIZING STRATEGY WITH AN EFFECTIVE BALANCED SCORECARD
}

\author{
Wendy Endrianto \\ Accounting and Finance Department, Faculty of Economic and Communication, Bina Nusantara University, \\ Jln. K.H. Syahdan No 9, Jakarta Barat, DKI Jakarta, 11480 \\ w.endrianto@binus.ac.id
}

\begin{abstract}
The research was conducted by studying the literature on the topic discussed. Presented descriptively in a systematic way to address each of the key discussion on this research, then connecting factors correlated with each other were finally seeking a conclusion the most effective method in meeting the company's goals. Then, through this study it can be concluded that in order to synergize between vision, mission and strategy of the company in regard to improving the company's performance is by communicating the balanced scorecard from top management down to the lower level of management so that all elements of the company know their respective roles in order to achieve company's goal.
\end{abstract}

Keyword: company strategy, vision, mission, financial performance, balance scorecard.

\section{INTRODUCTION}

Vision and mission are the starting point for strategic planning and corporate objectives. Key performance indicator (KPI) of the business will measure the extent to which the progress made in achieving objectives that flow from the vision. Efforts in achieving this vision will always involve a change towards a better future. There are risks in making the necessary changes in the course of this, but the leaders have to convince members that there is a greater risk if persisted in the current circumstances.

Susanto (2008) has explained that the determination of the vision and the mission begins with a look at where the position of the business now and where we want to be in the future and then describe a vision of the future for the business. To build an organization that can drive innovation and advanced through changes, organizational leaders must start with clear objectives and communicate them to everyone who has the same goal. A successful leader spends time with their team. They illustrate the vision, goals, and challenges faced in achieving the vision and objectives. Nothing is more important than communicating the visions and goals of the company. The leaders brief the people about the importance of their role in realizing the vision and meet the challenges ahead. They inspire subordinates to think, act and behave like entrepreneurs who are eager to find innovative ways to achieve success. Leadership gives spirit, vision, and psychological adhesive that unite the organization in all its activities. Management missions, maintain accountability and help ensure the realization of participation and commitment from the entire organization. We can not build passionate, committed, and enthusiastic organization or team members if they do not know where they are going. They have to find their own destination and then follow them. There are the importances of vision presentation in a dramatic way to provide durability.

In the development and formulation of vision and mission, it should be emphasized that a good formulation of the vision and mission should not only compiled and formulated alone since the 
beginning but must be communicated and shared with other members. The vision and mission are communicated and shared the main idea so that the company can continue to grow and enter into a new dimension. A shared vision together is a contribution that gives strength to the meaning of work. So ownership of the vision and mission of the whole member organization is important.

The mistake that often occur in a company is where the organizational structure always comes in advance rather than the strategy itself. The development of strategy should be the first thing to do, and then in order to implement this strategy, an appropriate structure can be drawn up. This is the trap that often happens; the strategy is made following the existing structure. Key performance indicator (KPI) of the business will measure the extent to which the progress made in achieving the vision and mission which is measured by seeing how far the performance of the employees in its favor. Performance is a real achievement that is displayed after the relevant person's duties and role in the organization or company. Performance systematically explains the relationship between work with the strengths and weaknesses that are owned by individuals or groups.

Rivai \& Basri (2005) have defined performance as a result or a person's overall success rate during a certain period in performing tasks compared to those possibilities, such as a standard work, the target or criteria that have been determined in advance has been agreed. While Mathis \& Jackson (2006) have stated that the performance is essentially what is done or not done by the employee. Performance management is the overall activities undertaken to improve the performance of the company or organization, including the performance of each individual and group work at the company.

Further related to the assessment of the performance of the company, the formulation of the Balanced Scorecard is often considered as ineffective implementation. Ineffectiveness is due to several factors and especially the inability of management to synergize between vision and mission of the company with the existing scorecard. No third synergetic these variables will be felt on the employees at the manager level down; it is associated with the assessment of their performance that led to the amount of the bonus received.

This research reviews how to maximize the strategy by creating an effective Balanced Scorecard so that they can work together to achieve the vision and mission of the company which is the agreement of all levels of an organization. The more effective synergy is formed, it will increase the competence of the company to compete in the business world because of the company's strategy is right on target. The Authors trust this study would provide a positive thought for the business world from the perspective of applied science about how to synergize the existing strategy with the Balanced Scorecard. In the midst of business competition intensifies, this method will be considered very effective and efficient in order to survive in the throes of economic and political conditions of the world today.

\section{METHODS}

The research is conducted by studying the literature on the topic discussed. There are two keywords that are discussed in this article, the strategy and the Balanced Scorecard, how to synergize in order to achieve the company's objectives effectively and efficiently. 


\section{RESULTS AND DISCUSSIONS}

Mulyadi (2007) has defined that the strategic management as a process used by managers and employees to formulate and implement strategies by providing the best customer value to realize the company's vision. Basically, the strategic management is an effort to build the management and employees of the company's future. The strategy is the main action pattern selected to realize the vision of the company, through the mission. From the definition above, there are four important conclusions as follows: (1) Strategic management is a process; (2) Process is used to formulate and implement strategies; (3) Strategy is used in the provision of customer best value for realizing the company's vision; (4) Managers and employees are perpetrators of strategic management.

Strategic Planning is a process of selecting the destination, the determination of strategies, strategic programs, and the establishment of methods that are needed to then be implemented in the operational activities of the company. Strategic planning consists of short-term planning and long-term well crafted to achieve company goals. There are three important reasons of strategic planning are: (1) strategic planning framework provides the basis for other planning; (2) strategic planning will facilitate an understanding of other forms of planning; (3) strategic planning is the starting point for the assessment of managers and organizational activities.

Hrebiniak (2005) has expressed several factors that obstruct the successful implementation of the strategy as follows: (1) Managers are trained to make plans but not trained to implement the plan. (2) The top managers of companies have confidence that the implementation of the strategy will be carried out by the company's human resources at a level below them. (3) There is a separation between those who make plans with which to implement the strategy as part of the planning. Whereas the planning and execution of the strategy is well aligned. Supposedly implementing the strategy is also a strategy formulator, so as to take into account the constraints of strategy execution that may occur in the future. (4) Execution strategy has a time period longer than the time required for strategy formulation. In the execution of long-term strategy, a variety of problems that are not visible at the time the plan was made to appear and it can exert pressure on the managers who implement the plan. Execution of strategy in the long-term also has a high risk of failure when the control system of the company is not able to provide adequate feedback about why a strategy failed to be implemented. (5) Managers often view of strategy execution as an act or a single step and not see it as a process. Whereas the execution of the strategy is a series of internal activities of the company are integrated and proceeds during the time the execution of the strategy. (6) Execution of strategy needs more people to be involved compared to the current strategy. This raises a variety of issues, such as coordination, communication, and incentives for implementing the strategy implementation throughout the organizational structure.

So it can be concluded that the strategic planning for the company is very important, because, without a strategy in managing the company, a manager looks like as if stepping into uncertainty. Strategic planning is an important internal factor to be considered in planning and decision making. Management with all the expertise required developing a suitable strategy for the company he leads. Management strategy helps companies to face the changes that are not anticipated by the company in its present condition. The global economic crisis is the main obstacle that is often ignored by all of the company when the economy is in a good and profitable condition, but when the situation turned upside down, the role of strategic management becomes very important and necessary. It would be too late for the company to implement a management strategy when the company is already on the verge of a major problem because time can not be predicted and the situation can not be estimated. Management strategy helps organizations collect, analyze, and manage information. They keep track of industry trends and competitive, developing forecasting models and scenario analysis, performance evaluation of companies and divisions, spot new market opportunities, identify business threats, creative and develop an action plan. 
The management strategy has a short-term organizational objective that must be achieved in order to achieve long-term goals. As long-term goals, annual goals must be measurable, quantitative, challenging, realistic, consistent, and prioritized. They should be set at the company, division, and functional at the level of large organizations. Annual goals must be expressed in terms of management, marketing, finance/accounting, production/operations, research and development, and information systems. The annual target is required for any long-term goals. Annual interest is particularly important in the implementation of the strategy, while the long-term goal is crucial in the formulation of the strategy. Annual Interest is an objective basis for allocating resources. The policy is a means of annual goals to be achieved. Policies include guidelines, rules and, procedures are established to support the efforts to achieve the stated objectives.

Changes in one of the major components in the model may require a change to one or all of the other components. For example, changes in the economy can be a great opportunity and require changes in the long-term objectives and strategies; the annual failure to achieve the goal may require a change in policy, or the main rival of the change in strategy may require a change of mission strong. Therefore, strategy formulation, implementation, and evaluation of activities should be carried out continuously, not just at the end of the year or semiannually. Strategy management process never really ends. The implementation of the strategy management process is usually more formal and larger in a large organization.

The balanced scorecard is the result of research Robert S. Kaplan and David P. Norton in 1992 which reported the results of a research project on multi-company and introduced a performance assessment methodology oriented strategic view to the future. Mulyadi (2007) has divided the two words "Balance Scorecard" to "Balance" and "Scorecard". "Balance" means impartial, while the "Scorecard" is a value card that will be used to plot the value that will be realized in the future. The balanced scorecard is an intention to measure performance in an executive balanced of various dimensions, namely financial and non-financial, both short term and long term. In the process, the balanced scorecard is not just a tactical or operational measurement system, but as a strategic management system for managing long-term strategy and yield management process as follows: (1) Clarify and translate vision and strategy; (2) Communicating and linking strategic objectives and measures; (3) Plan, set goals, and align strategic initiatives; (4) enhance strategic feedback and learning.

Kaplan and Norton (1996) have introduced four different perspectives of a company's activities that can be evaluated by management, as follows: (1) The financial perspective, how do we satisfy shareholders? (2) Customer perspective, how do we satisfy the customer? (3) Internal business process perspective, whether the processes are favored to reach the company's success? (4) Learning and growth perspective, how we will sustain the ability to change and improvement?These four perspectives of balanced scorecard can be seen in Figure 1.

Malina and Selto (2001) have found some companies that introduced the balanced scorecard to advance strategies. Scorecard has greatly influenced the views and actions of the company, both beneficial and detrimental. When the elements of the balanced scorecard are well designed and effectively communicated, it appears to motivate and influence the lower level managers to adjust their actions with strategy. Further, managers believe that these changes resulted in an increase in the performance of sub-units. However, there is also consistent evidence that the design flaws and deficiencies in the balanced scorecard strategic communications have affected the relationship between some of the top and the middle managers. Tensions exist because of the design of the balanced scorecard exacerbate a strong distinction between their views on the future opportunities. Deficiencies in communication generate distrust and reluctance to change. While certain weaknesses and deficiencies may be unique to the company studied, these findings appear to reflect generally on the issue of BSC design and usability. 


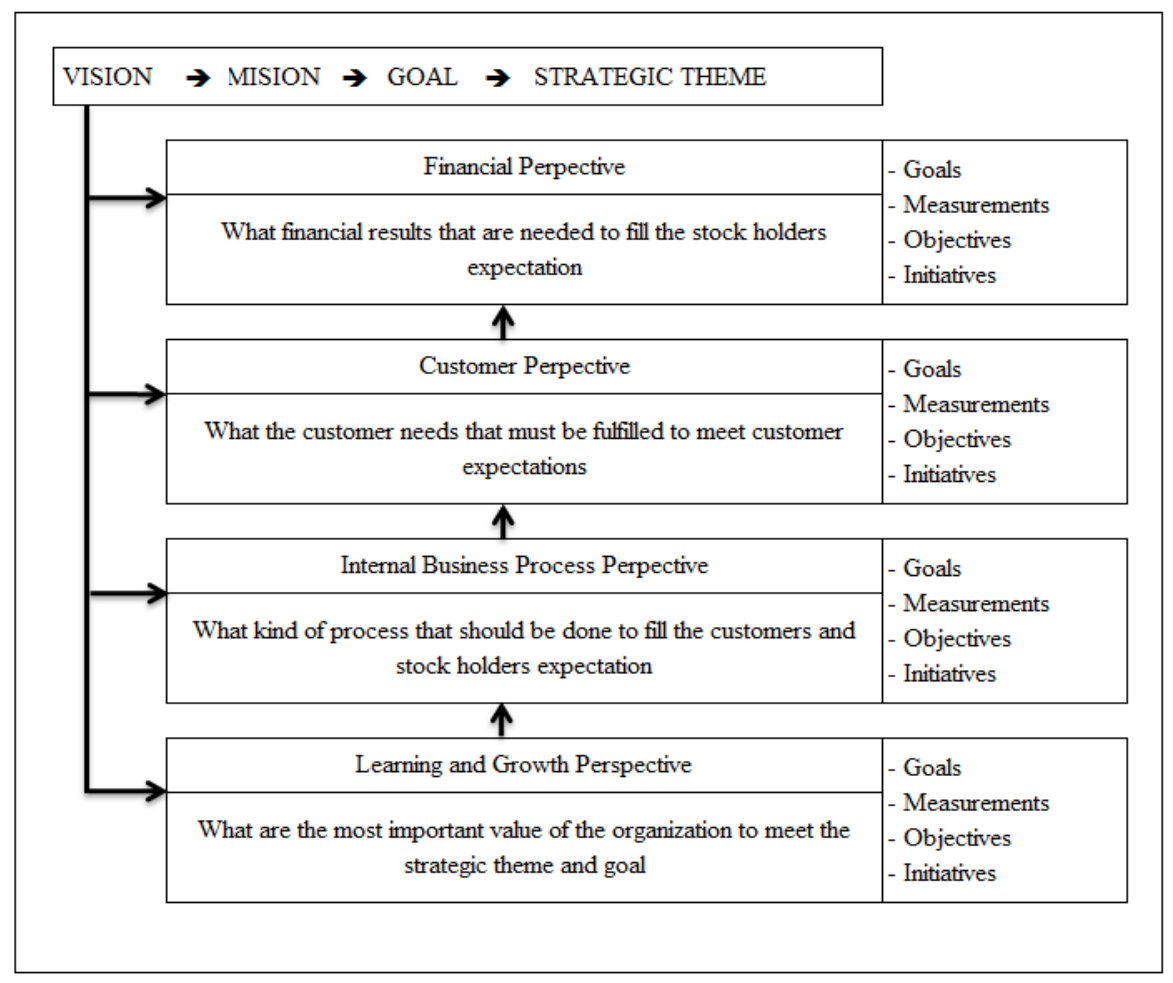

Figure 1 The Four Perspective of Balanced Scorecard

Gumbus (2006) has elucidated that the balance scorecard enables a focus on long-term growth versus a short-term focus on quarterly results. It also expands the traditional short-term financial metrics by including customer, operational efficience, and employee learning and growth measures. The card provides a balance between short and long-term goals and also balances what gets measuredfinancial plus quality and consumer and employee satisfaction dimensions. Balanced scorecard excellence in strategic planning system is the ability of the balanced scorecard in producing a strategic plan that has the characteristics, namely comprehensive, coherent, balanced, and measured.

Comprehensive characteristic in balanced scorecard is broaden perspectives covered in strategic planning, of which previously only limited on the financial perspective, the third extends another perspective, namely customer, process, and learning and growth. Expansion perspective of the strategic plan to the non-financial perspective yields benefits: (1) Promising financial performance manifold and continuous, as in planning, attention and effort focused on the perspective of nonfinancial personnel; (2) Enable the company to enter into a business environment that is complex, because the Balanced Scorecard produce a plan that covers a broad perspective, so that the resulting plan is able to respond to complex environmental changes.

Balanced Scorecard requires personnel to build their causal link between the various strategic objectives resulting in strategic planning. Each strategic objectives are applied in a non-financial pespektif must have a causal relationship with the financial targets, either directly or indirectly. In the end all strategic targets in a variety of non-financial perspectives should be geared in the financial startegik target, because in company is an institution who create wealthy, therefore, all activities must be able to generate additional wealth, either directly or indirectly. Coherent strategic targets generated in the system of strategic planning motivating personnel to be responsible in seeking strategic initiatives that are useful for generating financial performance. Strategic planning system that produces a coherent strategic objectives will promise continuous multiplication of financial performance, because the personnel are motivated to seek strategic initiatives that have benefits to the realization of 
strategic objectives in the learning and growth perspective, process, customer, or financial. In the balanced scorecard approach, there is no strategic initiatives that are not useful to achieve certain strategic goals. Coherent strategic targets promised doubling of financial performance is needed by the company to enter the competitive business environments, companies are required to become an institution multiplication of wealth and not just institutions creators of wealth. Various strategic that generated by the system of strategic planning have to realize strategic objectives by taking into account various core belief and core values set out in the strategy formulation system. The coherence accomplishment of such a promising company vision is based on the basic values of the company.

The balance of strategic targets that generated by the system of strategic planning is important for generating sustainable financial performance. There are four strategic objectives that need to be realized by the company are: (1) Shareholder value, the value for the owners of capital in the form of financial returns that doubled and sustainable; (2) Customer capital, product and service attribute, quality relationships, and the image is able to produce the best value for customers; (3) The process is productive and cost effective; (4) Human capital, information capital and organization capital. Helpless human resources arethe availability of information systems as an enabler, and organizations that enable human capital work together in synergy.

Measurable goals synergy that generated by the system of strategic planning promising strategic achievement of various targets. The balance scorecard measures the strategic goals that are difficult to quantify. Strategic targets in perspective customer, process and learning, and growth are objectives that are not easily measured, but in the balanced scorecard approach,targeted at the three perspectives nonfinancial can be sized to be managed, so that it can be realized. Thus, the degree of measurability of strategic goals in the third becomes a very promising perspective as seen in Figure 2 .

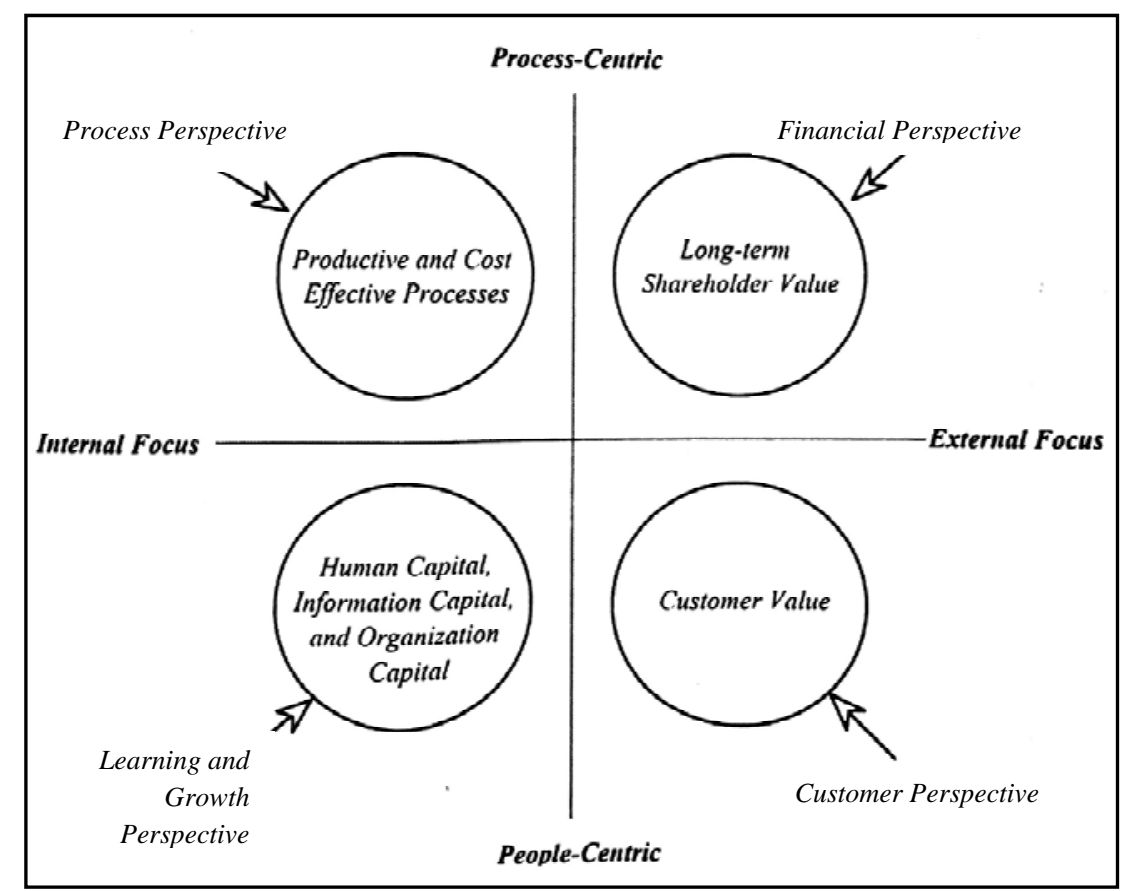

Figure 2 The Balance of Strategic Objectives in Strategic Planning (Source: Mulyadi, 2007)

External environment analysis provides insights to us about the various possibilities that we will achieve the opportunities and threats we face. Nonetheless, both recently confirmed it as an 
opportunity and a threat if we include an internal analysis as the analysis of the strengths and weaknesses of our own to be associated with opportunities and threats. Here we are required to be honest to ourselves that we are not mistaken in seeing the opportunities and threats that have been identified. Sometimes, opportunity that we see is not really for us, because there may be certain drawbacks that we have and difficult to repair associated with these opportunities.

Wheelen and Hunger (2008) have mentioned that we need to make sure whether all the resources we have served to increase the competitive advantage of our own. For that, we can do five process stages: (1) Identify and classify the resources of the company into two groups, namely the strengths and weaknesses. As we did the analysis of the external environment, internal environment analysis will lead to what are the strengths and weaknesses of our own. Once again of course this should be relative to the opportunities which we will take, or the threat which we must overcome. (2) Combining the strength of the company on certain capabilities and core competencies. By analyzing the internal strength, we can see the combinations that can be created in our overall capabilities. This combination expects to produce a synergy, which is the total benefit is greater than the capabilities if we run separately. (3) Assess the extent of their capabilities and these capabilities can generate competitiveness and profits. (4) Choose strategy to exploit the capabilities and competence of the company relative to the opportunities that exist. (5) Identify resource gaps and try to correct weaknesses.

In addition to the capability and competence, there are other terms that durability and initiability. Durability is the extent to which the capabilities and advantages of the company becomes obsolete or an advantage may be superior because of existing technology or a new way that makes excellence is irrelevant. While initiability concerns with how an emulated capabilities and advantages of the other parties. The greater the benefit received by the company on the capabilities and advantages will sooner followed or imitated by competitors.

In the midst of upheaval business environment faced by a company, it is not excessive if a company is required to have the capacity to adapt and the ability to overcome difficulties thus becoming an organizational excellence.Indeed, the real learning occur when people are constantly enhancing its capacity to create what he/she wanted to create (and usually something better). Without sufficient capacity to carry out the changes, we will not reap any fruit from a plan change. With the capacity and readiness of the changes we make, as well as reconstructing the company's business. Increased ability to do continuously perform systematically will gradually be able to prolong the survival of a company's business process innovation.

A performance management personnel aims to improve the accountability of personnel in the use of various resources in realizing the company's vision through the options. Personnel performance management consists of the following five integrated phases: (1) Planning the company's performance to be achieved; (2) Application of the role and core competency of personnel in realizing the company's performance; (3) Designing a reward system based on performance; (4) Measurement and evaluation of personnel performance; (5) Distribution of awards based on the results of the measurement and assessment of personnel performance.

Through five stages with integrated, quality management personnel performance improves significantly following: (1) Management of personnel performance includes the performance of employees, not just limited to the performance of managers who hold certain positions within the organization. Thus the performance management system is able to mobilize and direct all company personnel in winning the customer choice and realize the vision of the company. (2) Performance management personnel conducted applying spurred by fulfilling customer needs. In an environment in which the business customer in control, system performance management is driven by the fulfillment of customer needs will promise to improve the company's competitiveness in winning the customer choice. (3) The planned personnel performance through strategic planning system based on the 
balanced scorecard. As a result, the performance of which is formulated in the form of performance includes strategic and comprehensive perspective. Make strategic performance of each person's thinking long and comprehensive performance boosters make personnel focused to the real performance of the company. (4) Performance of personnel is defined as personnel success in realizing the company's strategic goals and the company's strategic objectives is the result of the translation of the mission, vision, basic beliefs, basic values, and corporate strategy. Thus the planned personnel performance is closely related to the vision and strategy of the company. Performance management system which links closely the performance of personnel with the strategy and vision of the company will promise the ability of all personnel to perform continious alignment to changes in the business environment that is entered by the company.

Figge, Schaltegger and Wagner (2002) have stated that balance scorecard can be applied to integrating environmental and social aspects into the successful implementation of both conventional corporate strategies and explicit corporate sustainability strategies. It is obvious that in the case of companies that have adopted explicit sustainability strategies environmental and social aspects will play a more prominent role in the sustainability balance scorecard. However, the openness of the approach also includes conventional firms widens the applicability of the balance scorecard from sustainable niche players to the far wider range of mainstream companies and helps them to move towards a more sustainable performance. It is obvious that the balance scorecard makes no statement on what kind of strategy should be chosen. Here again, it becomes clear that a sustainability balance scorecard is embedded in the wider context of strategic management.

\section{CONCLUSIONS}

To achieve better system performance, organizations should conduct performance measurement in order to have an objective and measurable management. Organizations need to evaluate the results of any activities carried out by the respective centers of responsibility compared to the benchmarks that have been set. In addition to external analysis company, internal analysis of the company is also very important to do and that is not too far in setting targets or goals and no one in defining a strategy. The first thing to do is to recognize the capability and competency; we need to ascertain whether all the resources we have served to increase the competitive advantage of our own. It is demanded to be true or not mistaken in seeing the opportunities and threats that have been identified. And to synergize between vision, mission, and strategy of the company in terms of improving the company's performance is by communicating the balanced scorecard, from top management down to lower level management so that all elements of the company know their respective roles in order to achieve a common goal.

\section{REFERENCES}

Figge, F., Hahn, T., Schaltegger, S., \& Wagner, M. (2002). The Sustainability Balanced Scorecard Linking Sustainaibility Management to Business Strategy. Business strategy and the Environment, 11 (5), 269-284. Retrieved May 1 ${ }^{\text {st }}$ 2015, from http://interscience.wiley.com.

Gumbus, A., \& Lussier, R. R. (2006). Entrepreneurs Use a Balanced Scorecard to Translate Strategy into Performance Measures. Journal of Small Business Management, 44(3), 407-425. Retrieved May 1 $1^{\text {st }}, 2015$ from http://onlinelibrary.wiley.com. doi: 10.1111/j.1540627X.2006.00179.x. 
Hrebiniak, L. G. (2005). Making Strategy Work: Leading Effective Execution and Change. Wharton School Publishing.

Kaplan, Robert S., \& Norton, D. (1996). Using the Balanced Scorecard as a Strategic Management System. Harvard Business Review, 74 (1), 75-85.

Malina, M. A., \& Selto, F. H. (2001).Communicating and Controlling Strategy: An Empirical Study of the Effectiveness of the Balanced Scorecard. Retrieved May $1^{\text {st }}, 2015$ from http://aaajournals.org

Mathis, R. L., \& Jackson, J. H. (2006). Human Resource Management: Manajemen Sumber Daya Manusia. Translated by Dian Angelia. Jakarta: Salemba Empat.

Mulyadi. (2007). Sistem Terpadu Pengelolaan Kinerja Personel Berbasis Balanced Scorecard. Yogyakarta: Unit Penerbit dan Percetakan STIM YKPN.

Rivai, V., \& Basri, A. F. M. (2005). Peformance Appraisal: Sistem yang tepat untuk Menilai Kinerja Karyawan dan Meningkatkan Daya Saing Perusahan. Jakarta: PT. Raja Grafindo Persada.

Susanto, A. B. (2008). Visi \& Misi: Langkah Awal Menuju Strategic Management. Jakarta: The Jakarta Consulting Group.

Wheelen, T. L., \& Hunger, J. D. (2008). Strategic Management and Business Policy. $11^{\text {th }}$ Edition. UK: Pearson International Edition. 